\title{
JUURNAL.RU
}

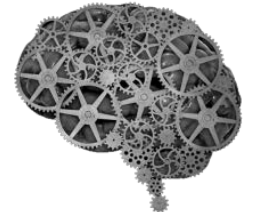

COMPANY GROUP "INTELLEKT"

Отрах B.B. Московский технологический институт Москва, Россия

doi: 10.18411/lj2016-6-4-04

\section{Предпосылки и эффект от внедрения единого расчетно-кассового центра}

Причинами к внедрению единого расчетно-кассового центра в текущей ситуации в РФ могут служить:

- Во-первых, единые расчетно-кассовые центры могут обеспечить стабильность систем жизнеобеспечения при переходе к рыночной модели управления жильем. При определенных условиях они, подобно биржам или клиринговым центрам, являются гарантом своевременного исполнения обязательств всех участников расчетов за жилищно-коммунальные услуги.

- Во-вторых, единый расчетно-кассовый центр консолидирует функцию фронт-офиса всех поставщиков жилищно-коммунальных услуг и управляющих компаний. То есть берет на себя основной объем работ по взаимодействию с населением через свою сеть абонентских пунктов.

Консолидация всех абонентских служб в рамках единой сети создает так называемый биллинговый эффект, то есть снижает суммарный уровень расходов на абонентское обслуживание населения за счет прекращения дублирования этих функций разными поставщиками услуг.

Для крупных поставщиков жилищно-коммунальных услуг (водоканал, электроснабжение) экономия составляет 1-3 \% от выручки. Для небольших 
поставщиков и управляющих компаний экономия может составлять до 40 \% и более.

Кроме биллингового эффекта наблюдается также рост собираемости платежей при условии, что используются соответствующие организационные и технологические решения.

Помимо информационно-расчетных функций и функций агента по сбору и диспетчеризации платежей, единые расчетно-кассовые центры могут предоставлять дополнительные услуги информационной поддержки как для управляющих компаний, так и для некоторых поставщиков. Например:

- ведение паспортного учета;

- ведение технического паспорта здания;

• учет заявок жильцов, регистрация актов аварий и недопоставок;

- регистрация показаний приборов учета и поддержка информации о самих приборах (номера, поверки и т. д.);

-

Поддержка централизованной абонентской базы и технической информации о жилье создает еще один важный фактор стабильности позволяет обеспечить замену управляющей компании без потери ценной информации и, как следствие, создать условия для реальной конкуренции между управляющими компаниями.

Таким образом, для управляющей компании единый расчетный центр является эффективным финансовым агентом, гарантом своевременности расчетов, качества и полноты информационных фондов.

Но для того, чтобы единый расчетно-кассовый центр соответствовал этой роли, необходимо предъявить понятную для контрагентов систему собственности и управления, создать устойчивую и выгодную для всех сторон схему договорных отношений и обеспечить информационно-технологическую поддержку всех вышеперечисленных функций. 
Практика показывает, что единый расчетно-кассовый центр может оказывать три группы услуг:

- информационно-расчетные услуги:

- ведение баз данных;

- выполнение начислений и ведение сальдо расчетов,

- объяснение расчетов населению,

- подготовка отчетов для поставщиков и управляющих компаний;

- услуги финансового агентирования (сбор платежей, а также организация работы субагентов по сбору платежей);

- дополнительные информационные или сервисные услуги (паспортный учет, техническая паспортизация, поддержка систем учета и съема показаний приборов и т. д.).

Вторую и третью группы услуг единый расчетно-кассовый центр может не предоставлять, но без информационно-расчетных функций его существование не имеет смысла.

Наличие единой базы данных и промышленной информационной системы позволяют единому расчетно-кассовому центру консолидировать все группы функций на высоком технологическом уровне, который, как правило, недоступен для каждого поставщика или управляющей компании в отдельности.

Современный единый расчетно-кассовый центр использует три основных «инструмента»: обученный коллектив специалистов, промышленную информационную систему, технологическую инфраструктуру (офисную и компьютерно-сетевую).

Для организации работы единого расчетно-кассового центра требуется: разработать оптимальную для данной территории модель работы единого расчетно-кассового центра, заключить договора с поставщиками жилищнокоммунальных услуг и управляющих компаний, развернуть технологическую и 
инфраструктуру, внедрить информационную систему, обучить персонал и руководство работе с системой. 